\title{
The improvement of solidwaste management in Cibodas Botanical Garden through environmental economic valuation using the travel cost method
}

\author{
Iwan Juwana ${ }^{1, *}$ and Muhammad Sirdar Albar ${ }^{1}$ \\ ${ }^{1}$ Institut Teknologi Nasional Bandung, Department of Environmental Engineering, PHH Mustafa 23 Bandung, Indonesia
}

\begin{abstract}
Cibodas Botanical Garden (CBG) is believed to have high environmental value for its function as conservation area and beautiful scenery. However, prior to this research, there is lack of economic valuation to determine the total value of $\mathrm{CBG}$, including its environment. The local government, on the other hand, needs such environmental economic valuation to execute better decisions related to the CBG. This study aims at providing the mostly-needed economic valuation through the application of Travel Cost Method. The Travel Cost Method (TCM) is a method to calculate the economic value of products or services that do not own market value. This method utilises total cost of consumers who travel to certain places, preferably tourist destinations. The cost spent by consumers are considered as their willingness to pay (WTP) for the visited destination(s). In this study, TCM is used by preparing questionnaires for Cibodas visitors, analysing the results of the questionnaires, calculating the total economic value (TEV) of Cibodas, determining the consumer surplus, and proposing environmental programs at CBG. At the end, it was calculated that the TEV of Cibodas Botanical Garden is IDR113,072,532,700 with average WTP of the visitors IDR202,484 per visitor and the consumer surplus of IDR32,344 per visitor. Also, this study reveals that solid waste management improvement at CBG can be funded by potential income from the consumer surplus.
\end{abstract}

\section{Introduction}

Tourist destinations have been included in nearly everyone's plan during holiday periods. Indonesia is bestowed with abundant natural resources, some of them have become tourist attractions. One of the globally known tourist natural destinations is the Cibodas Botanical Garden [1-3].

The Cibodas Botanical Garden (CBG) is located in the area of Gunung Gede Pangrango National Park, Cianjur Regency. The 125 ha garden initially served as an acclimatisation of vegetation imported from other countries, particularly vegetation with rich in value and have high economic value [4-6]. However, since the year 2003 the CBG has been defined as both conservation and tourist area. Since then, offering the beautiful view and affordable entrance fee, the CBG has become a holiday destination for local and foreign tourists.

Due to one of its functions as conservation area of Cianjur region, along with its fresh air and beautiful view, it is by no surprise that the place has attracted growing visitors each year. Unfortunately, environmental values of the $\mathrm{CBG}$ are often neglected during decision making related to the area due to the lack of information of such environmental values [1-3, 7]. Therefore, a study to quantify the values of environmental issues of CBG is of utmost important.
This study aims at quantifying economic values of the environmental aspects of $\mathrm{CBG}$, using the travel cost method (TCM) [8-11]. With this method, the willingness to pay of visitors is obtained from the total expenditure of visitors visiting CBG. In its application, this method allows researchers to calculate economic surplus of selected respondents. This consumer surplus can also be used to assist not only local government, but also the $\mathrm{CBG}$ manager, to improve the management of $\mathrm{CBG}$ in the future. The information on the consumer surplus will allow CBG manager to explore possibilities of improving $\mathrm{CBG}$ using the potential income from the consumers.

\section{Methods}

In general, the steps undertaken in this study are shown in Figure 1. The figure shows that the economic valuation study of the $\mathrm{CBG}$ is initiated by literature review. The review of literature is an important step in this study as it provides information on current conditions related to the study. When undertaking this economic valuation study, it is inevitable to explore past studies on economic valuation of environmental services in other places. Also, it is highly beneficial to compare available methods for various environmental products and services valuation and how the methods are applied in different situations. This can only be done through sound literature review. In order to expand the benefits,

\footnotetext{
*Corresponding author: juwana@itenas.ac.id
} 
the review of existing literatures in this study was undertaken for both national and international contexts. This way, the review provides the state of the art of similar studies holistically.

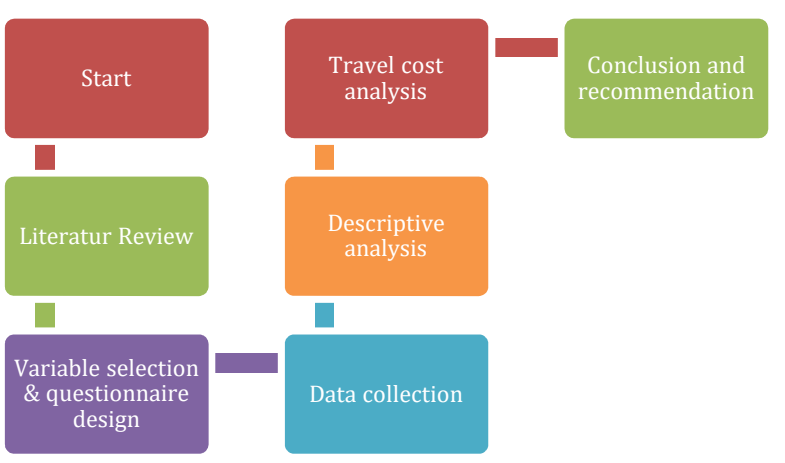

Fig. 1. Steps for the environmental valuation study of Cibodas National Park.

The literature review was then followed by the next step namely the variable selection for this study. The selection of variables is required to, later, analyse factors affecting the willingness to pay of respondents in this study. Basically, the variables were selected from past studies similar to this study. Some other literatures, such as books and government regulations, to enrich the variables in this study,were also used. At the end of this step, identified variables were gender, age, occupation, income, number of visit, distance to location, type of transport, and education level. In general, these variables are assumed to affect the willingness to pay of visitors visiting the Cibodas Botanical Garden. Based on these variables, a questionnaire was then designed and tested.

The next step was to collect necessary data, both primary and secondary ones. Primary data was obtained from the field observation and distribution of questionnaires to $\mathrm{CBG}$ visitors. The number of respondents was defined using Slovin formula with $8 \%$ error. The secondary data was taken from related institutions, such as Cultural and Tourism Agency of Cianjur Regency and CBG Management.

After all required data were collected, the study was followed by data calculation and analysis. The analysis included both the descriptive analysis and the travel cost analysis. The descriptive analysis offers individual phenomenon, such as socio-economic characteristics, of the selected respondents. This analysis was undertaken to support the valuation questions given to the respondents [12]. Then, the travel cost analysis was undertaken to obtain the value of respondents' willingness to pay related to CBD. The travel cost analysis for this study is done through the following:

1. Identification of the recreation area (environmentbased tourist attraction) as a case study.

2. Distribution of questionnaires to collect data from respondents on their expenditures to the location, number of visits, and others.

3. Undertake willingness to pay (WTP) calculation, which includes individual WTP and summation of WTP to be considered as total economic value of the location.

4. Drawing a demand curve based on respondent's answers during the questionnaire distribution, and followed by calculating its consumer surplus.

\section{Results and discussions}

\subsection{Number of respondents}

The number of respondents to be given the questionnaires was based on the Slovin Formula with error margin of $8 \%$. As the total visitors of $\mathrm{CBG}$ is 558,427 per year (data of 2016), the number of respondents in this study is calculated as:

$$
\begin{aligned}
& n(8 \%)=\frac{N}{1+N(e) 2} \\
& =\frac{558,427}{1+558,427(0.08) 2}=156 \text { respondents }
\end{aligned}
$$

Sugiyono [13-16] stated that Slovin formula allows the maximum of $10 \%$ error threshold. Thus, the use of 8 $\%$ in this study for the error is justified. A smaller error threshold was not opted in this study as the number of respondents will exceed researcher's ability.

\subsection{Questionnaire results}

As mentioned earlier, variables used in this study are gender, age, occupation, income, number of visit, distance to location, type of transport, and education level. After the questionnaire distribution, the results are shown in the following table.

\begin{tabular}{|c|c|c|c|}
\hline Variable & Remark & $\%$ & Analysis \\
\hline \multirow[b]{2}{*}{ Gender } & Male & $56 \%$ & \multirow{2}{*}{$\begin{array}{l}\text { There were more male } \\
\text { respondents in the study } \\
\text { because during the } \\
\text { interview, if visitors came } \\
\text { with their family, only the } \\
\text { head of the family were } \\
\text { interviewed (mostly male) }\end{array}$} \\
\hline & Female & $34 \%$ & \\
\hline \multirow{5}{*}{ Age } & $17-23$ у.о & $35 \%$ & \multirow{5}{*}{$\begin{array}{l}\text { The CBG offers natural } \\
\text { views and beautiful scenes } \\
\text { suitable for self-taking } \\
\text { photos. Thus, it attracts } \\
\text { visitors between } 17-23 \\
\text { years old at the most. In } \\
\text { addition, the entrance fee is } \\
\text { affordable for such age } \\
\text { group. }\end{array}$} \\
\hline & 24 - 30 у.о & $18 \%$ & \\
\hline & 31 - 37 у.о & $26 \%$ & \\
\hline & 38 - 44 у.о & $13 \%$ & \\
\hline & $45-51$ у.о & $8 \%$ & \\
\hline \multirow{4}{*}{ Occupation } & Students & $24 \%$ & \multirow{4}{*}{$\begin{array}{l}\text { Office workers are believed } \\
\text { to have hectic and } \\
\text { monotonous working } \\
\text { schedule, thus needing the } \\
\text { break from their offices. } \\
\text { This seems to cause the } \\
\text { level of visits from office } \\
\text { workers, along with the } \\
\text { affordable entrance fee. }\end{array}$} \\
\hline & Entrepreneur & $21 \%$ & \\
\hline & Office workers & $41 \%$ & \\
\hline & Other & $14 \%$ & \\
\hline
\end{tabular}

Table 1. Results of questionnaires distribution. 
Table 1. Continued

\begin{tabular}{|c|c|c|c|}
\hline Variable & Remark & $\%$ & Analysis \\
\hline \multirow{5}{*}{ Income } & $<$ IDR $1,000,000$ & $13 \%$ & \multirow{5}{*}{$\begin{array}{l}\text { The CBG is considered low } \\
\text { to medium level of } \\
\text { entrance fee, which is very } \\
\text { suitable and affordable for } \\
\text { visitors in the salary range } \\
\text { of IDR } 1,000,000 \text { to IDR } \\
3,000,000\end{array}$} \\
\hline & $\begin{array}{c}\text { IDR1,000,000 } \\
- \\
\text { IDR3,000,000 }\end{array}$ & $50 \%$ & \\
\hline & $\begin{array}{c}\text { IDR4,000,000 } \\
- \\
\text { IDR6,000,000 }\end{array}$ & $26 \%$ & \\
\hline & $\begin{array}{c}\text { IDR7,000,000 } \\
- \\
\text { IDR9,000,000 }\end{array}$ & $8 \%$ & \\
\hline & $>$ IDR $9,000,000$ & $3 \%$ & \\
\hline \multirow{4}{*}{$\begin{array}{c}\text { Number of } \\
\text { visit }\end{array}$} & Once & $53 \%$ & \multirow{4}{*}{$\begin{array}{l}\text { More first-time visitors are } \\
\text { found because people tend } \\
\text { to visit other places after } \\
\text { their first visits. However, } \\
\text { the second time visits is } \\
\text { still quite high }(37 \%) \text {. }\end{array}$} \\
\hline & 2 times & $37 \%$ & \\
\hline & 3 times & $3 \%$ & \\
\hline & $>3$ times & $7 \%$ & \\
\hline \multirow{4}{*}{$\begin{array}{l}\text { Distance to } \\
\text { location }\end{array}$} & $5-20 \mathrm{~km}$ & $19 \%$ & \multirow{4}{*}{$\begin{array}{l}\text { People from distance are } \\
\text { likely more curious about } \\
\text { places they hear from other } \\
\text { friends, relatives or even } \\
\text { from websites of social } \\
\text { media. Thus, they are more } \\
\text { visitors from long distance } \\
\text { found in this study. }\end{array}$} \\
\hline & $20-50 \mathrm{~km}$ & $19 \%$ & \\
\hline & $50-100 \mathrm{~km}$ & $41 \%$ & \\
\hline & $>100 \mathrm{~km}$ & $21 \%$ & \\
\hline \multirow[b]{3}{*}{$\begin{array}{l}\text { Type of } \\
\text { transport }\end{array}$} & Personal & $63 \%$ & \multirow{3}{*}{$\begin{array}{l}\text { The CBG, which is located } \\
\text { at the feet of } \\
\text { GedePangrango Mountain } \\
\text { and about } 1-2 \mathrm{~km} \text { from } \\
\text { main road, is best to reach } \\
\text { with own transportation. At } \\
\text { the moment, there is no } \\
\text { reliable and convenient } \\
\text { public transportation is } \\
\text { available to the location. }\end{array}$} \\
\hline & Hire & $23 \%$ & \\
\hline & Public transport & $11 \%$ & \\
\hline \multirow[b]{3}{*}{$\begin{array}{l}\text { Education } \\
\text { level }\end{array}$} & $\begin{array}{c}\text { Junior high } \\
\text { school }\end{array}$ & $1 \%$ & \multirow{3}{*}{$\begin{array}{l}\text { It seems logical that the } \\
\text { higher education level of an } \\
\text { individual, the higher the } \\
\text { needs for vacation. It might } \\
\text { also be caused by the } \\
\text { earning of the higher } \\
\text { educated individuals } \\
\text { compared to the lower ones } \\
\text { that lead to relatively } \\
\text { higher educated people } \\
\text { visiting CBG. }\end{array}$} \\
\hline & $\begin{array}{c}\text { Senior high } \\
\text { school }\end{array}$ & $48 \%$ & \\
\hline & $\begin{array}{l}\text { Higher } \\
\text { education }\end{array}$ & $51 \%$ & \\
\hline
\end{tabular}

\subsection{Willingness to pay and total economic value}

Using Travel Cost Method, the willingness to pay of the individuals (respondents) is based on the total expenses of respondents during their visits to CBG. In this study, it is calculated that the average of respondents' total expenses equals to IDR202,484. The value is obtained from 156 respondents during the survey. Each individual was asked their expenses related to the following items: transportation, accommodation (if any), food, souvenirs, other expenses spent in CBG. Once the WTP for each respondent was obtained, the value is then used to calculate the total economic value for the $\mathrm{CBG}$.

The total economic value was calculated with the following equation [17]:

$$
T E V=\overline{W T P \times N}
$$

Where:

$T E V=$ total economic value (in local currency, Rupiah)

$W T P=$ average of willingness to pay (Rupiah/person)

$N=$ number of visitors in a year (visitors)

Using the the above equation, and average number of CBG visitors as many as 558,427 (in 2016), the total economic value of $\mathrm{CBG}$ is calculated as follow:

$$
\begin{aligned}
\text { TEV of Cibodas }= & \text { IDR202,484 Ч 558,427 } \\
& =\text { IDR113,072,532,700 }
\end{aligned}
$$

With this information, decision makers of $\mathrm{CBG}$ are now able to map the environmental values of CBG along with other market-based values, such as land and facility values, whenever needed. Thus, in the future, decisions related to CBG should also include the environmental values obtained in this study. This is an important step forward because in the past environmental considerations were, mostly, not included in the decision making as information on economic values of the environment was not available. Benefits from similar study can be found in other studies undertaken by Seenprachawong [18] and Lankia, Neuvonen, \& Pouta [19]. In this study, the results from the TCM studies were able to assist local governments for improving the coral reel and water quality in respective study locations.

\subsection{Consumer surplus}

Consumer surplus is the difference between what customers spent on certain products/services and their willingness to pay [20]. This consumer surplus can be calculated using the area between demand curve and the average willingness to pay, as illustrated in Figure 2 [21]. In order to obtain the area, the demand curve is drawn from the data in the Table 2.

Table 2. Willingness to pay and number of visits.

\begin{tabular}{|c|r|}
\hline $\begin{array}{c}\text { Number } \\
\text { of visits }\end{array}$ & Willingness to pay (IDR) \\
\hline 1 & 214,747 \\
\hline 2 & 201,828 \\
\hline 3 & 173,750 \\
\hline$>3$ & 151,136 \\
\hline
\end{tabular}

Then, based on the above table, the demand curve can be drawn as shown in Figure 2.

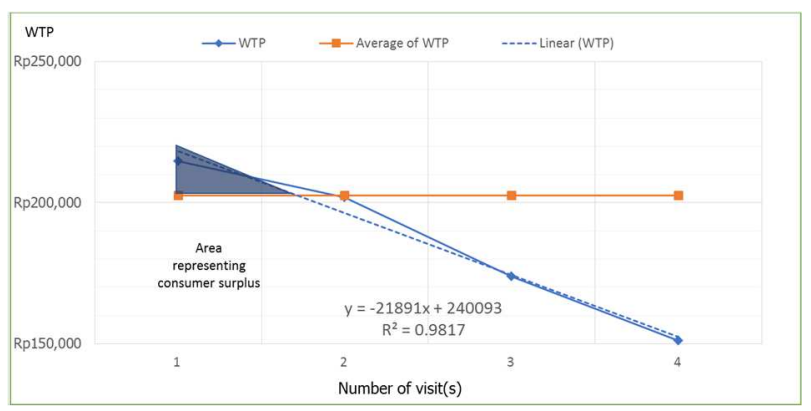

Fig. 2. Demand curve for calculating consumer surplus. 
The area representing the consumer surplus was calculated by calculating the triangle shape between the WTP Linear and the WTP average lines with the following formula:

$$
A=\frac{h \times b}{2}
$$

Where:

$A=$ triangle area

$h=$ height of the triangle

$b=$ base of the triangle

The height of the triangle can be obtained by first determining the intersection of the linear line with the $\mathrm{Y}$ axis $(\mathrm{x}=0)$ :

$$
\begin{aligned}
Y(W T P) & =-21,891 x+240,093 \\
& =-21,891(0)+240,093 \\
& =240,093
\end{aligned}
$$

Then, the value was subtracted with the WTP average IDR 202,448 Thus, the height of the triangle was calculated as:

$$
\begin{gathered}
\mathrm{h}=240,093-202,448 \\
=37,609
\end{gathered}
$$

Further, the base of the triangle is obtained from the intersection of linear line with the average WTP on the X axis. Thus, it was calculated as:

$$
\begin{aligned}
Y(W T P) & =-21,891 x+240,093 \\
202,484 & =-21,891 x+240,093 \\
x & =1.72
\end{aligned}
$$

At the end, the triangle area was calculated as:

$$
\begin{gathered}
A=\frac{h \times b}{2} \\
A=\frac{37,609 \times 1.72}{2} \\
A=32,344
\end{gathered}
$$

Therefore, the consumer surplus obtained in this study equals to IDR 32,344 per visitor. The figure can also be used to calculate yearly surplus for CBG by multiplying the individual consumer surplus with the total visitors in one year. If the recent visitors of $\mathrm{CBG}$ in 2016 are used $(558,427$ visitors $)$, the yearly consumer surplus of CBG is:

$$
\begin{aligned}
\text { Yearly consumer suprlus } & =\text { IDR } 32,344 \text { X 558,427 } \\
& =\text { IDR } 18,061,762,890
\end{aligned}
$$

This information on the value of consumer surplus value can be used by $\mathrm{CBG}$ manager to consider the improvement of $\mathrm{CBG}$ facilities using the potential revenue provided the consumer surplus, including environment-related facilities such as solid waste management and sanitation facilities.

\section{The use of this study - improvement of CBG solid waste management}

This part elaborates how the results of this study can be used to assist decision makers on how to improve the management of solid waste in Cibodas Botanical Garden [22].

Based on questions asked to the respondents and observations in the $\mathrm{CBG}$, environment-related that can be improved in the area was the solid waste management. During the interview, $77 \%$ of the respondents believed that solid waste management in CBG should be improved.

In general, the management of $\mathrm{CBG}$ has undertaken solid waste management practices. For example, throughout the area there were already 139 rubbish bins to serve the visitors.

The waste from those bins was transported to the landfill twice a day, which account to approximately 500 $\mathrm{kg}$ of waste. These wastes were taken from both the visitors areas, as well as the vegetation nursery activities.

Further, it also important to note that $\mathrm{CBG}$ also has composting facility in the area of $392 \mathrm{~m}^{2}$. Each year, this composting facility produces 27 tonnes of compost which is distributed to farmers and shops surrounding CBG.

In $\mathrm{CBG}$, for each batch, as much as one ton of solid waste is composted using natural and simple composting process. The organic waste is poured with composting activator, then covered by plastic mats and regularly mixed. On the other hand, the anorganic waste has not been treated in any process. In CBG, any anorganic waste is dumped on open land without any treatment, as illustrated in Figure 3

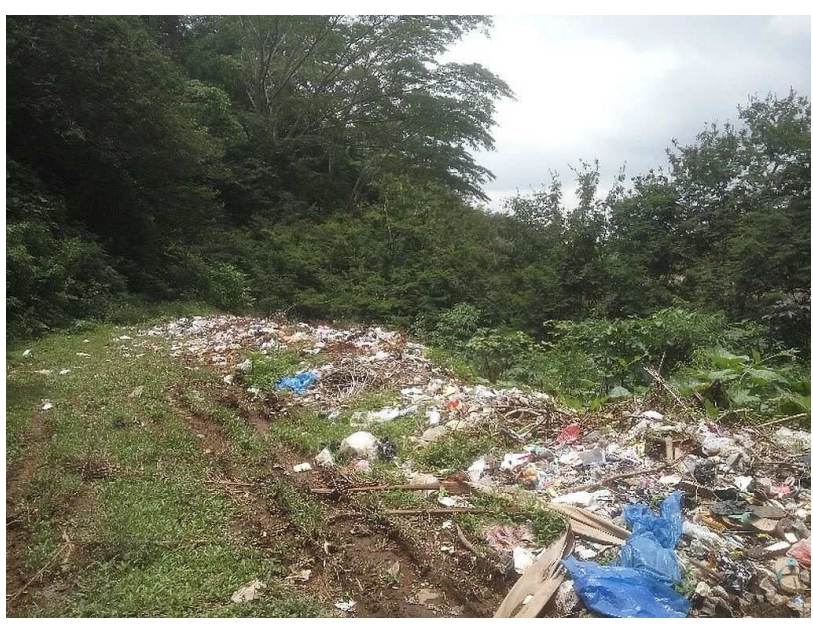

Fig. 3. Dumping of inorganic at $\mathrm{CBG}$.

\subsection{Volume of generated waste}

In this study, the waste generated in CBG was calculated based on the waste being transported to the sorting area, before composting or landfilling, as follow: 


\section{Waste Volume $=$ volume of truck container $x$ compression factor}

(4)

Volumeoftruckcontainerxcompressionfactor $=8$

$\mathrm{m}^{3} /$ day $\mathrm{x} 2$

$=16 \mathrm{~m}^{3} /$ day

$=584 \mathrm{~m}^{3} /$ year

\subsection{Proposed solid waste improvement programs}

Based on the observation, calculation and analysis on the solidwaste management, two improvement practices are proposed: more rubbish bins and a recycle centre in CBG.

\subsubsection{More rubbish bins and billboards}

As calculated earlier, the total waste generated in CBG is $16 \mathrm{~m}^{3} / \mathrm{d}$ (equal to $16,000 \mathrm{~L} / \mathrm{d}$ ). If this volume is divided with the maximum volume of each rubbish bin, $70 \mathrm{~L}$, then ideally in CBG there 229 rubbish bins are needed compared with 139 bins currently available. Thus, it is proposed that $\mathrm{CBG}$ provides 90 more rubbish bins to accommodate all the visitors. As for the location of the new rubbish bins are to distribute evenly throughout the CBG area.

Along with more rubbish bins, this study also proposes dissemination of the importance of waste awareness from the visitors. During field observation, litters were still found in the $\mathrm{CBG}$, which show the lack of awareness of some visitors regarding solid waste. Thus, along with the addition of rubbish bins, this study also recommends the use of waste-related billboardsas reminders for the visitors on the importance of solid waste management in $\mathrm{CBG}$.

\subsubsection{Recycle centre}

Another program proposed in this study is the initiation of recycle centre near the location of landfill. Currently, waste transported to the transfer station inside the CBG is not treated with any technique. The waste is only dumped in an open area. Thus, this study proposes the improvement of the transfer station to function as a recycle centre. In most tourist areas, waste is composed of $48 \%$ organic waste and $52 \%$ of inorganic waste. In the $\mathrm{CBG}$, organic waste is mostly from leaves and branches from the vegetation, while the inorganic waste is mostly from food and beverage containers. This recycle centre is expected to function as sorting area, cleaning and packaging before transported to customers.

\subsubsection{Required budget}

As it is mentioned earlier, the numbers of required rubbish bins and billboards are 90 and 115 respectively. The costs for each bin and billboard are IDR200,000 and IDR50,000 Thus, the total cost required for the bins and billboards is:
Total cost $=(90 x$ IDR200,000) $+(115 x$ IDR50,000 $)$

Total cost $=($ IDR18,000,000) $+($ IDR $5,750,000)$

Total cost $=$ IDR23,750,000

As for the recycle centre, the calculation of required cost is based on the criteria given by the Ministry of Public Works. According to the Decree of Ministry of Public Works [23], the investment cost for a recycle centre in Indonesia is IDR500,000,000 per $3 \mathrm{~m}^{3} /$ day of waste. Thus, as the generated solid waste in the CBG equals to $16 \mathrm{~m}^{3} /$ day, required investment cost is:

Investment Cost $=$ IDR500,000,000 $\times \frac{16 \mathrm{~m}^{3} / \text { day }}{3 \mathrm{~m}^{3} / \text { day }}$
Investment Cost $=$ IDR2,666,666,667

Then, total budget for the improvement of solid waste management in $\mathrm{CBG}$ can be compared with the consumer surplus obtained earlier, as shown in the Table 3.

Table 3. Potential extra income and allocation comparison.

\begin{tabular}{|c|c|c|}
\hline & Potential extra income & Allocation \\
\hline $\begin{array}{c}\text { Consumer } \\
\text { surplus }\end{array}$ & IDR2,792,135,000 & \\
\hline Rubbish bins & & IDR18,000,000 \\
\hline Posters & & IDR5,750,000 \\
\hline Recycle centre & & IDR2,666,666,667 \\
\hline Total & IDR2,792,135,000 & IDR2,690,416,667 \\
\hline
\end{tabular}

Table 3 shows that the total spending for the improvement of solid waste management in $\mathrm{CBG}$ is below the potential extra income obtained from the consumer surplus.

\section{Conclusions}

The use of travel cost method in this study has revealed the IDR202,484 willingness to pay value of each respondent, with the total economic value of $\mathrm{CBG}$ is IDR $18,061,762,890$ per year

The information of consumer surplus from this study can be used by CBG manager to make plans regarding the improvement of CBG facilities.

The cost for the improvement of solid waste management in CBG can be fulfilled consumers, as the total required cost is lower than the consumer surplus obtained from this study.

Decision makers of CBG will be able to make more environmentally-friendly decisions related to $\mathrm{CBG}$, with the use of results of this study.

\section{References}

1. Hidayat, I. User Satisfaction Assessment To EduEco Tourism Services Of Cibodas Botanical 
Garden. in IOP Conference Series: Earth and Environmental Science. IOP Publishing. (2017)

2. Khotimah, H., T. Djatna, and Y. Nurhadryani. Tourism recommendation based on vector space model using composite social media extraction. in Advanced Computer Science and Information Systems (ICACSIS), 2014 International Conference on. IEEE. (2014)

3. Minaputri, E.F., et al., Economic assessment of Cibodas botanical garden as environment and human health service-based ecotourism object. 농업 과학연구, 44(1): p. 123-132. (2017)

4. Hatta, H., et al., Phenology and Growth Habits of Tropical Trees Long-term Observations in the Bogor and Cibodas Botanic Gardens, Indonesia. National Science Museum Monographs, 30: p. 1436. (2005)

5. Mutaqien, Z. and M. Zuhri, Establishing a longterm permanent plot in remnant forest of Cibodas Botanic Garden, West Java. Biodiversitas Journal of Biological Diversity. 12(4). (2011)

6. Zuhri, M. and Z. Mutaqien, The spread of nonnative plant species collection of Cibodas Botanical Garden into Mt. Gede Pangrango National Park. Journal of Tropical Life Science, 3(2): p. 74-82. (2013)

7. Juwana, I., N. Muttil, and B. Perera, Application of west java water sustainability index to three water catchments in west java, Indonesia. Ecological indicators, 70: p. 401-408. (2016)

8. Armbrecht, J., Use value of cultural experiences: $A$ comparison of contingent valuation and travel cost. Tourism Management, 42: p. 141-148. (2014)

9. Hanauer, M.M. and J. Reid, Valuing urban open space using the travel-cost method and the implications of measurement error. Journal of environmental management, 198: p. 50-65. (2017)

10. Kawsar, M.H., et al., Quantifying recreational value and the functional relationship between travel cost and visiting national park. International Journal of Environmental Planning and Management, 2015. 1(3): p. 84-89. (2005)

11. Zhang, F., et al., The recreational value of gold coast beaches, Australia: An application of the travel cost method. Ecosystem Services, 11: p. 106114. (2015)

12. Muharram, R., Willingness to Pay Pengguna Angkutan Umum untuk Pelayanan Bus Rapid Transit (BRT) Koridor I di Kota Surakarta: Aplikasi Metode Contingent Valuation. Universitas Sebelas Maret. (2015)

13. Sugiyono, D., Statistika untuk penelitian. Bandung: CV. Alfabeta, (2006)

14. Juwana, I., N. Muttil, and B. Perera, Uncertainty and sensitivity analysis of West Java Water Sustainability Index-A case study on Citarum catchment in Indonesia. Ecological indicators, 61: p. 170-178. (2016)

15. Field, A., An adventure in statistics: the reality enigma: Sage. (2016)
16. Juwana, I., N. Muttil, and B. Perera, Application of West Java water sustainability index to Citarum catchment in West Java, Indonesia. Water Science and Technology: Water Supply, 14(6): p. 11501159. (2014)

17. Pearce, D.W., The economic value of forest ecosystems. Ecosystem health, 2001. 7(4): p. 284296. (2005)

18. Seenprachawong, U., An economic analysis of coral reefs in the Andaman Sea of Thailand, in Marine and Coastal Ecosystem Valuation, Institutions, and Policy in Southeast Asia. Springer. p. 31-45 (2016)

19. Lankia, T., M. Neuvonen, and E. Pouta, Effects of water quality changes on the recreation benefits of swimming in Finland: Combined travel cost and contingent behavior model. Water Resources and Economics (2017)

20. Handoyo, E., Eksistensi Pedagang Kaki Lima (Studi Tentang Kontribusi Modal Sosial terhadap Resistensi PKL di Semarang). Doktor Studi Pembangunan Program Pascasarjana UKSW (2012)

21. Djijono, Valuasi Ekonomi Menggunakan Metode Travel Cost Taman Wisata Hutan di Taman Wan Abdul Rachman, Propinsi Lampung (2002)

22. Juwana, I., B. Perera, and N. Muttil. Conceptual framework for the development of West Java water sustainability index. in 18th World IMACS Congress and MODSIM09 International Congress on Modelling and Simulation (2009)

23. Works, M.o.P., Penyelenggaraan Prasarana Dan Sarana Persampahan Dalam Penanganan Sampah Rumah Tangga Dan Sampah Sejenis Sampah Rumah Tangga: Jakarta (2013) 